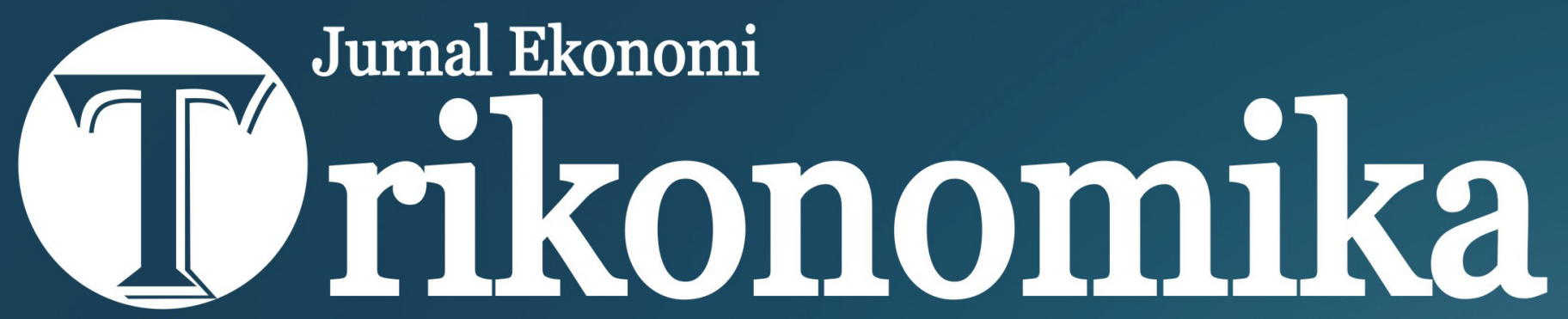




\section{DAFTAR ISI}

Trikonomika, Volume 13, No. 1, Juni 2014

Pengaruh Otonomi dan Akuntabilitas Perguruan Tinggi terhadap Kinerja Manajerial

Isnaeni Nurhayati

Keseimbangan Jangka Pendek dan Jangka Panjang Nilai Tukar Rupiah terhadap Dollar Amerika

Horas Djulius, Yudi Nurdiansyah

Kajian Kepemimpinan Transformasional, Komitmen Karyawan, Motivasi, Kepuasan Kerja, dan Kinerja Karyawan

Edy Saptono $21-48$

Pengaruh Kualitas Pelayanan terhadap Kepuasan Mahasiswa Program Ekstensi Fakultas Ekonomi Universitas Jambi

Yenny Yuniarti $49-61$

Determinan Profitabilitas Bank: Suatu Studi pada Bank yang Terdaftar di BEI

Jaja Suteja, Gerinata Ginting

Faktor Determinan Minat Wirausaha Mahasiswa Fakultas Ekonomi dan Bisnis Universitas

Negeri Gorontalo

Herwin Mopangga

Pengaruh Upah dan Pengalaman Kerja terhadap Produktivitas Karyawan

Kerajinan Ukiran Kabupaten Subang

Ardika Sulaeman

Analisis Harga Saham dan Rata-Rata Abnormal Return Sebelum dan Sesudah Ex-Dividend Date (Studi pada Emiten Indeks Kompas-100)

Alvin Mulya Hidayati $101-107$

Pengaruh Manajemen Laba Akrual dengan Pendekatan Revenue Discretionary Model terhadap Kinerja Perusahaan Manufaktur di Bursa Efek Indonesia 


\title{
Faktor Determinan Minat Wirausaha Mahasiswa Fakultas Ekonomi dan Bisnis Universitas Negeri Gorontalo
}

\author{
Herwin Mopangga \\ Fakultas Ekonomi dan Bisnis, Universitas Negeri Gorontalo \\ J1. Jend. Sudirman No.6 Kec. Kota Tengah, Kota Gorontalo 96128 \\ E-Mail: herwin@ung.ac.id
}

\begin{abstract}
This research aims to describe the actual condition of the entrepreneurial student at the Faculty of Economics and Business, Gorontalo State University (FEB-UNG), identifying the determinant factor of student entrepreneurial intention and to formulate alternative ways to improve the entrepreneurial intention. Use qualitative descriptive method, primary data obtained by 50 selected respondent, and secondary data from student division of FEB-UNG office. Research concludes, first, it is generally, student entrepreneurial intention still relatively low, evidenced by the lack of FEB students become entrepreneur, low involvement in training/workshop and seminar about entrepreneurship inside or outside of campus as well as the lack of number of business plan that competed in Program of Student Creativity (PKM). Second, relatively low of entreprenurial intention is highly determined by the lack supporting of parents and family who works as civil servant or private employees, public perception and also entrepreneurial learning atmosphere and facilities that have to be acces inside of campus. Third, the solutions offered is multiplied the frequence of entrepreneurial practices, carried out of learning contextual periodically, provide the entrepreneurial facilities, business incubator program, business plan writing contest, budget allocation and entrepreneurial network integrated with local stakeholder.
\end{abstract}

Keywords: student entrepreneurs, determinant factors, entrepreneurial intention.

\begin{abstract}
ABSTRAK
Penelitian ini bertujuan mendeskripsikan kondisi aktual wirausaha mahasiswa di Fakultas Ekonomi dan Bisnis Universitas Negeri Gorontalo (FEB-UNG), mengidentifikasi faktor penentu minat wirausaha mahasiswa dan merumuskan metode pendekatan untuk meningkatkan minat wirausaha mahasiswa. Menggunakan pendekatan deskriptif kualitatif, data primer diperoleh dari kuesioner 50 responden terpilih sedangkan data sekunder dari sub bagian kemahasiswaan FEB-UNG. Penelitian menyimpulkan pertama, secara umum minat berwirausaha relatif rendah dibuktikan dengan kurangnya individu dan kelompok mahasiswa FEB menjadi pelaku wirausaha, rendahnya keterlibatan mahasiswa dalam pelatihan dan pembekalan wirausaha didalam maupun luar lingkungan kampus serta kurangnya jumlah proposal bisnis yang ikut berkompetisi di Program Mahasiswa Wirausaha (PMW) Dikti. Kedua, kecenderungan rendahnya minat wirausaha sangat dipengaruhi oleh rendahnya dukungan orang tua dan keluarga yang mayoritas pegawai dan karyawan swasta, persepsi masyarakat dan iklim pembelajaran kewirausahaan serta dukungan akademik. Ketiga, solusi yang ditawarkan adalah memperbanyak frekuensi praktek kewirausahaan, melaksanakan pembelajaran kontekstual secara periodik, menyediakan dan melengkapi fasilitas kewirausahaan di kampus, mengadakan program inkubator bisnis dan lomba penulisan business plan, peningkatan alokasi anggaran wirausaha mahasiswa serta membangun jaringan wirausaha terpadu dengan stakeholder lokal.
\end{abstract}

Kata Kunci: wirausaha mahasiswa, faktor determinan, minat wirausaha 


\section{PENDAHULUAN}

Kemiskinan, kesenjangan sosial dan spasial, pengangguran usia produktif, kelangkaan pangan dan menipisnya cadangan energi merupakan tantangan besar bagi bangsa Indonesia memasuki pasar bebas dan persaingan global. Solusi yang bisa ditempuh untuk dapat keluar dari kompleksitas persoalan diatas menuntut jiwa, pikiran dan tindakan kreatif dan inovatif, diantaranya melalui penciptaan wirausaha muda (young entrepreneur) dalam jumlah dan kualitas memadai. Indonesia memiliki 95 persen usaha kecil, 3 persen usaha menengah, dan 2 persen usaha besar dengan penyerapan tenaga kerja oleh usaha kecil dan menengah mencapai 50 persen. Ini menunjukkan bahwa usaha kecil menengah tumbuh subur dan berkontribusi sangat signifikan pada pendapatan masyarakat dan penyerapan tenaga kerja.

Ciputra (2009:32) mengemukakan bahwa wirausahamerupakansolusitepatuntukmenyelesaikan masalah pengangguran dan kemiskinan di Indonesia, karena dengan hanya berbekal ijazah tanpa kecakapan entrepreneurship, siapkanlah diri untuk antripekerjaan karena saat ini pasokan tenaga kerja lulusan perguruan tinggi tidak sebanding dengan peluang kerja yang tersedia. Saat ini, ketika Amerika Serikat sudah memiliki 11,5 hingga 12 persen, Singapura 7 persen serta Cina dan Jepang 10 persen, maka wirausaha Indonesia baru mencapai 0,24 persen dari total 238 juta jiwa, dan itu berarti masih dibutuhkan sekitar 4 juta wirausaha baru. Padahal bangsa ini menghasilkan sekitar 700 ribu orang sarjana baru setiap tahunnya, dan memiliki kemampuan untuk melipatgandakan pertumbuhan ekonomi, pendapatan total maupun perkapita, menurunkan angka pengangguran dan kemiskinan bilamana mampu meningkatkan jumlah wirausaha sukses dengan pemanfaatan teknologi yang tumbuh pesat dewasa ini. Menurut Badan Pusat Statistik, jumlah wirausaha di Indonesia melonjak dari 0,24 persen tahun 2009 menjadi 1,65 persen di akhir 2013. Namun jumlah ini harus terus ditingkatkan menuju jumlah ideal, yakni 2 persen dari total penduduk. Sebab wirausaha yang akan menjadi penggerak pembangunan ekonomi tanah air. Faktanya, minat mahasiswa untuk berwirausaha masih rendah. Di tahun 2011 tercatat 10.000 lebih mahasiswa mengikuti program sarjana wirausaha namun hanya 5.000-an yang merealisasikannya. Dari
4,8 juta mahasiswa hanya 7,4 persen yang meminati wirausaha (Kemenkop UKM, 2012).

Kewirausahaan dapat diartikan sebagai semangat, sikap dan perilaku atau kemampuan seseorang dalam menangani usaha dan atau kegiatan yang mengarah pada upaya mencari, menciptakan, menerapkan cara kerja, teknologi dan produk baru dengan meningkatkan efisiensi dalam rangka memberikan pelayanan yang lebih baik dan atau memperoleh keuntungan yang lebih besar. Kewirausahaan adalah suatu proses kreativitas dan inovasi yang mempunyai risiko tinggi untuk menghasilkan nilai tambah produk yang bermanfaat bagi masyarakat dan mendatangkan kemakmuran bagi wirausahawan. Kewirausahaan itu dapat dipelajari walaupun ada juga orangorang tertentu yang mempunyai bakat dalam hal kewirausahaan (Kemendikbud, 2012; Soegoto, 2009).

Zimmerer (2002:12) menyatakan salah satu faktor pendorong pertumbuhan kewirausahaan disuatu negara terletak pada peranan universitas melalui penyelenggaraan pendidikan kewirausahaan. Pihak universitas bertanggung jawab dalam mendidik dan memberikan kemampuan wirausaha kepada para lulusannya dan memberikan motivasi untuk berani memilih berwirausaha sebagai karir mereka. Pihak perguruan tinggi perlu menerapkan pola pembelajaran kewirausahaan yang konkrit berdasarmasukan empiris untuk membekali mahasiswa dengan pengetahuan yang bermakna agar dapat mendorong semangat mahasiswa untuk berwirausaha ( $\mathrm{Wu}$ and $\mathrm{Wu}, 2008$; Suherti dan Sirine, 2011).

Kewirausahaan sebagai perilaku yang terencana terkait dengan minat yang dimiliki oleh seseorang. Krueger dan Carsrud dalam Siswadi (2013) menekankan bahwa minat berwirausaha merupakan prediktor terbaik untuk perilaku berwirausaha. Hasil penelitian Gorman et al. (1997) serta Kourilsky dan Walstad(1998) juga menyatakan minat wirausaha pada diri mahasiswa adalah sumber berdirinya suatu usaha baru. Minat wirausaha (entrepreneurial intention) dapat diartikan sebagai langkah awal dari suatu proses pendirian sebuah usaha yang umumnya bersifat jangka panjang (Lee and Wong, 2004). Sejumlah faktor telah diprediksi dapat mempengaruhi minat seseorang untuk berkarir sebagai wirausaha; seperti keinginan untuk menjadi wirausaha, faktor kepribadian, keterampilan wirausaha dan ketersediaan modal (Zain et al., 2010; 
Kurnianto dan Sulistya, 2012). Priyanto (2008), menyebut jiwa wirausaha dipengaruhi oleh faktor internal, eksternal dan kontekstual. Faktor internal berupa sifat-sifat personal, sikap, kemauan dan kemampuan yang memberi kekuatan individu untuk berwirausaha. Faktor eksternal seperti lingkungan keluarga, lingkungan dunia usaha, lingkungan fisik dan lingkungan sosial ekonomi. Faktor psikologi dan sosiodemografi juga ditemukan dalam sejumlah studi sebagai determinan perilaku kewirausahaan. Faktor psikologi mencakup (i) kebutuhan untuk berprestasi/ need of achievement, (ii) inisiatif dan kreativitas, (iii) kecendrungan mengambil resiko/the propensity to take risk, (iv) kepercayaan diri dan locus of control, (v) self-esteem dan perilaku inovatif, (vi) nilai-nilai yang dianut dan tujuan personal, serta (vii) leadership (Hisrich and Peters, 2000:71; Rianti, 2003:38). Faktor sosiodemografi meliputi jenis kelamin, umur dan pekerjaan orang tua (Rasheed, 2000; Nishanta, 2008). Faktor kontekstual bersama faktor internal dan eksternal merupakan kerangka integral yang mempengaruhi minat wirausaha. Gurbuz dan Aykol (2008) menegaskan bahwa pendidikan, pengalaman dan pembekalan kewirausahaan sejak usia dini dapat meningkatkan potensi seseorang untuk menjadi wirausahawan, disamping dukungan pihak akademik, sosial dan lingkungan usaha.

Tabel 1. Statistik Ketenagakerjaan

Propinsi Gorontalo Tahun 2012

\begin{tabular}{lll}
\hline \multicolumn{1}{c}{ Kategori } & Jumlah*) & \multicolumn{1}{c}{$\%{ }^{* *}$ ) } \\
\hline Angkatan kerja & 466.073 & 36 (Populasi) \\
$\begin{array}{l}\text { Penduduk bekerja } \\
\text { Tingkat pengangguran }\end{array}$ & 445.729 & 95,6 (angkatan kerja) \\
terbuka & 20.344 & 4,36 (angkatan kerja) \\
$\begin{array}{l}\text { Penganggur lulusan } \\
\text { perguruan tinggi }\end{array}$ & \pm 8.000 & 36 (pengangguran terbuka) \\
$\begin{array}{l}\text { Lulusan lainnya: } \\
\text { SD \& SLTP }\end{array}$ & -- & 4 (pengangguran terbuka) \\
SLTA / sederajat & -- & 60 (pengangguran terbuka) \\
\hline
\end{tabular}

Keterangan: *) jumlah absolut

**) perbandingan terhadap

Sumber: Berita Resmi Statistik No. 59/11/75/Th.VI. 5 November 2012

Meningkatkan jumlah wirausaha mahasiswa sekaligus menciptakan lapangan kerja baru di tataran lokal Gorontalo semakin penting dan mendesak mengingat kecenderungan bertambahnya pengangguran terdidik. Data BPS Gorontalo dalam Tabel 1. berikut ini menunjukkan pengangguran intelektual lulusan perguruan tinggi mencapai lebih sepertiga dari pengangguran terbuka, sedangkan lulusan SLTA sederajat menyentuh 60 persen.

Ini fakta menyedihkan mengingat lapangan kerja sektor informal menjadi wirausahawan masih cukup potensial dengan memanfaatkan sumber daya alam dan teknologi yang tersedia. Niode (2007:98) mengatakan sektor UMKM potensial di Gorontalo adalah pada bisnis jasa, eceran, distribusi, agribisnis/ pertanian, dan bisnis manufaktur. Sedangkan Mopangga dkk (2013:195) menyebutkan jagung dan ikan dapat diandalkan Provinsi Gorontalo menjadi kompetensi inti industri, UMKM serta peluang wirausaha mahasiswa. Kreativitas dan inovasi mahasiswa menghasilkan produk Martabak Jagung Gorontalo (Mak Jago) serta proposal bisnis stik jagung ikan (JaguAn) memenangkan Seleksi Bisnis Plan Terbaik Tenaga Penyuluh Lapangan - Industri Kecil Menengah (TPL-IKM) 2012.

Persoalannya, bagaimana menumbuhkan minat wirausaha dikalangan mahasiswa dan faktor-faktor apa yang mempengaruhi mereka untuk memilih karir berwirausaha, masih menjadi pertanyaan dan memerlukan kajian lebih lanjut. Hal-hal inilah yang menjadi latar belakang penelitian ini dengan rumusan permasalahan yang ingin dianalisis adalah bagaimana kondisi aktual (existing condition) wirausaha mahasiswa Fakultas Ekonomi dan Bisnis Universitas Negeri Gorontalo, faktor-faktor apa yang menentukan minat wirausaha mahasiswa FEB-UNG, dan bagaimana metode pendekatan untuk meningkatkan minat wirausaha mahasiswa FEB-UNG.

\section{METODE}

\section{Kerangka Pikir Penelitian}

Pendidikan kewirausahaan dalam berbagai aspeknya diharapkan mampu memberikan pencerahan bagi para mahasiswa dalam meniti karir sebagai wirausaha. Hal tersebut sangatlah penting untuk mengantisipasi melonjaknya jumlah angka pengangguran terdidik di Indonesia yang semakin tinggi. Tujuan utama penelitian ini adalah untuk mendeskripsikan kondisi aktual (existing condition) wirausaha mahasiswa FEB-UNG; mengidentifikasi 
Kondisi aktual:

- Jumlah mahasiswa pelaku wirausaha

- Minat mahasiswa berwirausaha

- Intervensi lembaga terhadap kegiatan wirausaha mahasiswa
Kondisi ideal:

- > $25 \%$ mahasiswa FEB melaksanakan kegiatan wirausaha

- $>75 \%$ mahasiswa FEB berminat untuk melaksanakan kegiatan/merintis wirausaha

- $>30 \%$ program khusus dan alokasi anggaran utk meningkatkan minat wirausaha mahasiswa
Data Primer:

- Identitas diri

- Rata-rata nilai MK Kewirausahaan mahasiswa

- Pelatihan kewirausahaan yg pernah diikuti

- Latar belakang pekerjaan orang tua

- Pengalaman/apakah pernah berwirausaha selama menempuh pendidikan di FEB-UNG
Data Sekunder:

- Jumlah mahasiswa reguler 2012/2013

- Jumlah dan latar belakang pendidikan staf pengajar MK Kewirausahaan

- Struktur kurikulum

- Sarana dan prasarana praktek yang dimiliki

- Jenis program lembaga terkait wirausaha mahasiswa

- Alokasi anggaran untuk wirausaha mahasiswa

Hasil yg diharapkan:

- Data riil mahasiswa pelaku wirausaha di FEB-UNG

- Identifikasi faktor determinan minat wirausaha mahasiswa di FEB-UNG

- Rumusan alternatif cara/upaya/pendekatan yg bisa ditempuh lembaga untuk meningkatkan minat wirausaha mahasiswa di FEB-UNG

Gambar 1. Diagram alir Rencana Penelitian 
faktor-faktor penentu minat wirausaha mahasiswa FEB-UNG; serta merumuskan alternatif cara/upaya/ pendekatan untuk meningkatkan minat wirausaha mahasiswa FEB-UNG. Responden penelitian ini adalah gabungan mahasiswa pelaku wirausaha maupun non wirausaha yang diambil secara terpilih (purposive), berjumlah 50 orang. Adapun kerangka pikir penelitian ini dapat diringkaskan dalam diagram alir berikut.

\section{Populasi dan Sampel}

Penelitian ini dilakukan di Fakultas Ekonomi dan Bisnis (FEB) Universitas Negeri Gorontalo (UNG) selama 6 bulan pada tahun 2014. Populasi penelitian berjumlah 2.546 orang mahasiswa aktif dan terdaftar di sub bagian kemahasiswaan FEB-UNG. Sampel ditarik secara sengaja (purposive) berjumlah 50 orang yang terdistribusi relatif merata disemua jurusan dan program studi. Kriteria pokok dari sampel (responden) adalah telah lulus Mata Kuliah Kewirausahaan cukup baik dengan skor 4 (A) atau 3 (B). Selain kriteria tersebut, terdapat beberapa kriteria tambahan yaitu: (a) sudah dan atau belum pernah mengikuti pelatihan/ pembekalan kewirausahaan, (b) sudah merintis usaha sendiri dan masih berjalan, (c) usaha yang dirintisnya sudah berhenti karena berbagai faktor dan alasan, atau (d) baru sebatas berniat membuka usaha sendiri.

Sampel yang tergolong kecil/sedikit harus dilakukan karena kurangnya jumlah mahasiswa yang aktif dalam kegiatan wirausaha, pernah mengikuti pelatihan dan pembekalan wirausaha maupun pernah menyusun proposal usaha (business plan).

\section{Data dan Sumber Data}

Data yang dihimpun dalam penelitian ini terdiri dari data primer dan data sekunder. Data Primer dikumpulkan dari hasil wawancara dengan mahasiswa menggunakan kuisioner tentang sifat/prilaku untuk mengukur tingkat kewirausahaan (Alma, 2009). Data yang diambil dari kuisioner adalah: identitas diri (nama, program studi, umur, jenis kelamin), pelatihan kewirausahaan yang pernah diikuti, rata-rata nilai mata kuliah kewirausahaan yang diperoleh masingmasing mahasiswa yang telah mengontraknya, latar belakang pekerjaan orang tua, pengalaman/apakah pernah melakukan kegiatan usaha selama menempuh pendidikan di FEB-UNG.

Data sekunder dikumpulkan dari Bagian Kemahasiswaan Fakultas Ekonomi dan Bisnis yang terdiri dari: data jumlah mahasiswa reguler semua angkatan yang aktif tahun akademik 2012/2013, jumlah staf pengajar mata pelajaran kewirausahaan dan latar belakang pendidikannya, struktur kurikulum dan sarana dan prasarana praktek yang dimiliki mahasiswa.

\section{Teknik Pengumpulan Data}

Pengumpulan data dilakukan dengan beberapa cara, yaitu: (1) pengamatan (observation), yaitu data dikumpulkan melalui pengamatan langsung terhadap mahasiswa FEB-UNG, (2) penyebaran kuesioner, yaitu memberikan kuesioner pada mahasiswa yang akan dijadikan responden, dan (3) pendokumentasian, yaitu mengumpulkan data dengan mencatat data-data yang sudah tersedia di sub bagian kemahasiswaan FEB-UNG.

\section{Metode Analisis Data}

Untuk mencapai tujuan pertama, peneliti menindaklanjuti hasil observasi dan mencantumkan dalam daftar pendek (shortlist) mahasiswa pelaku wirausaha dan non wirausaha. Untuk mencapai tujuan kedua, digunakan analisis atas penilaian kuesioner sifat-sifat yang mencirikan seorang wirausahawan.

Mahasiswa dapat dikategorikan potensial melaksanakan wirausaha mahasiswa bila memiliki nilai mata kuliah Kewirausahaan diatas rata-rata, pernah mengikuti pelatihan terpadu kewirausahaan, berasal dari lingkungan keluarga wirausaha serta pernah mencoba berwirausaha. Untuk mencapai tujuan ketiga, digunakan analisis atas data-data sekunder. Lembaga dalam hal ini FEB-UNG secara relatif lebih mudah meningkatkan minat wirausaha mahasiswa bila ditunjang oleh banyaknya tenaga pengajar yang kompeten dan berpengalaman dengan mata kuliah Kewirausahaan, struktur kurikulum yang mendukung program wirausaha mahasiswa, sarana dan prasarana praktek yang menunjang, jenis program lembaga terkait wirausaha mahasiswa serta alokasi anggaran yang memadai untuk pengembangan wirausaha mahasiswa.

\section{HASIL}

\section{Profil Institusi}

Fakultas Ekonomi dan Bisnis (FEB) merupakan fakultas ke delapan di Universitas Negeri Gorontalo (UNG), dibentuk berdasarkan Keputusan Rektor 
UNG Nomor 282/H47.A2/OT/2009 tanggal 17 Maret 2009. Salah satu alasan berdirinya fakultas ini adalah diharapkan dan diyakini mampu berperan dan berkontribusi nyata dalam pengembangan dan pembinaan secara berkelanjutan terhadap peningkatan kualitas sumber daya manusia Indonesia, khususnya di kawasan timur Indonesia, terutama di wilayah Provinsi Gorontalo dan sekitarnya. Lembaga ini telah menetapkan Tujuan Umum yang harus dicapai yakni "mewujudkan peran kelembagaan UNG dalam perspektif manajemen Badan Layanan Umum sekaligus sebagai masa transisi UNG menuju perguruan tinggi yang berstatus Badan Hukum Pendidikan. FEB UNG juga diharapkan dapat menerapkan dan mengaktualisasikan Tata Nilai UNG sebagai Kampus I'KTIBAR (Ikhtiar, Ibadah dan Reaktualisasi-diri) agar menjadi perilaku dan norma kehidupan kampus sekaligus sebagai manifestasi tridharma perguruan tinggi untuk lebih mengokohkan UNG sebagai Universitas Peradaban.

Pengembangan kualitas Sumber Daya Manusia oleh FEB-UNG tidak terbatas melalui pendidikan dan pengajaran, penelitian dan pengabdian masyarakat saja tetapi juga mengupayakan penciptaan sarjana baru yang terampil dan siap membuka usaha. Hal ini tercermin dari poin ketiga Misi FEB yaitu "Membina dan mengembangkan budaya kewirausahaan bagi sivitas akademika Fakultas Ekonomi dan Bisnis" kemudian disokong oleh poin ketiga Tujuan Khusus yakni "Menciptakan budaya entrepreneurship yang memilikikemampuan kewirausahaan dan kemandirian tinggi serta keterampilan dalam bidang ekonomi dan bisnis untuk bersaing di era pasar bebas".

Fakultas Ekonomi dan Bisnis Universitas Negeri Gorontalo menaungi tiga jurusan, Pendidikan Ekonomi, Manajemen dan Akuntansi. Dari komposisi mata kuliah dan struktur kurikulum yang ada menunjukkan bahwa selain menjalankan Tridarma perguruan tinggi (pendidikan pengajaran, penelitian dan pengabdian kepada masyarakat), FEB juga menjalankan tugasnya menyiapkan tenaga-tenaga unggul untuk berkarir di sektor formal maupun membangun usaha secara mandiri. Selain muatan teoritis, mata kuliah tertentu juga diboboti dengan praktek baik dalam ruang kelas maupun luar ruang kelas disesuaikan dengan situasi, kondisi dan kebutuhan.

Tetapi bila diperhatikan dampak dari sejumlah mata kuliah terutama Kewirausahaan yang disampaikan dalam perkuliahan maupun praktikum tidak berkorelasi positif dengan meningkatnya minat mahasiswa berwirausaha. Hal ini bisa dilihat dari data yang diperoleh dari sub bagian kemahasiswaan FEB-UNG Januari 2013, bahwa jumlah individu maupun kelompok mahasiswa yang menjadi pelaku wirausaha sangat sedikit, kurang dari 100 orang - Jika dibandingkan dengan jumlah mahasiswa reguler FEB-UNG Tahun Akademik 2013/2014 yang berkisar 2.546 orang maka angka pelaku wirausaha mahasiswa hanya sekitar 3,9\% dari total mahasiswa. Salah satu faktor penentu minimnya jumlah pelaku wirausaha mahasiswa dapat ditelusuri dari aspek minat (intention) mahasiswa dalam berwirausaha.

\section{Gambaran Umum Responden}

Responden yang diambil sebanyak 50 mahasiswa, 32 orang perempuan (64 persen) dan 18 orang lakilaki (36 persen). Lebih dari 80 persen responden berusia antara 19-22 tahun dan sisanya diatas 22 tahun. Berdasarkan data pada Tabel 2., mahasiswa terdistribusi hampir merata pada ketiga jurusan; Akuntansi 36,16 persen, Manajemen 35,99 persen dan Pendidikan Ekonomi 27,85 persen.

Oleh Karena itu mahasiswa yang bertindak sebagai responden yang kami golongkan dalam wirausaha mahasiswa dan non wirausaha mahasiswa diklasifikasikan menurut jurusan/program studi adalah dari programm studi Akuntansi 18 orang, (10 wirausaha, 8 non wirausaha), 18 orang dari program studi Manajemen (10 wirausaha, 8 non wirausaha) dan 14 orang dari program studi Pendidikan Ekonomi (6 wirausaha, 8 non wirausaha), seperti ditunjukkan Tabel 3.

\section{Karakteristik Objek Penelitian}

Mahasiswa FEB-UNG di semester genap tahun akademik 2013-2014 ini berjumlah 2.546 orang. Jumlah itu terdistribusi di tiga jurusan; Pendidikan Ekonomi 699 orang, Manajemen 881 orang dan Akuntansi 868 orang. Responden dalam penelitian ini adalah semua mahasiswa yang telah lulus mata kuliah Kewirausahaan dengan nilai cukup baik (A/B) yang kami akses dari Sistim Informasi Akademik Terpadu (SIAT) dan pernah mengikuti pelatihan Kewirausahaan baik didalam (internal) maupun diluar lingkungan kampus. Di antara responden, ada yang sudah merintis usaha dan aktif dalam kegiatan wirausaha, tetapi mayoritas tidak/belum berwirausaha. 
Tabel 2. Jumlah Mahasiswa FEB-UNG

Menurut Jurusan/Program Studi dan Angkatan

\begin{tabular}{|c|c|c|c|c|c|c|c|c|c|}
\hline \multirow[b]{2}{*}{ Jurusan } & \multirow[b]{2}{*}{ Program Studi } & \multicolumn{7}{|c|}{ Angkatan } & \multirow[b]{2}{*}{ Sub Total } \\
\hline & & $\begin{array}{l}2013- \\
2014\end{array}$ & $\begin{array}{c}2012- \\
2013\end{array}$ & $\begin{array}{c}2011- \\
2012\end{array}$ & $\begin{array}{l}2010- \\
2011\end{array}$ & $\begin{array}{l}2009- \\
2010\end{array}$ & $\begin{array}{c}2008- \\
2009\end{array}$ & $\leq 2007$ & \\
\hline \multirow[t]{2}{*}{ Pendidikan Ekonomi } & Pendidikan Ekonomi S1 & 195 & 142 & 163 & 149 & 35 & 11 & 4 & 699 \\
\hline & Ekonomi Pembangunan S1 & 10 & & & & & & & 10 \\
\hline \multirow[t]{2}{*}{ Manajemen } & Manajemen S1 & 232 & 225 & 202 & 196 & 15 & 8 & 3 & 881 \\
\hline & Administrasi Perkantoran D3 & 15 & 11 & 6 & 3 & 0 & 0 & 0 & 35 \\
\hline \multirow[t]{3}{*}{ Akuntansi } & Akuntansi S1 & 247 & 205 & 222 & 163 & 23 & 7 & 1 & 868 \\
\hline & Akuntansi D3 & 1 & 28 & 12 & 9 & 1 & 0 & 2 & 53 \\
\hline & & & & & & & & & 2546 \\
\hline
\end{tabular}

Sumber: Sub bagian Kemahasiswaan dan Operator Sistim Informasi Akademik Terpadu (SIAT) FEB-UNG, Maret 2014

Tabel 3. Distribusi Mahasiswa Jurusan/Prodi Menurut Pelaku Wirausaha dan Non Wirausaha

\begin{tabular}{llcc}
\hline \multicolumn{1}{c}{ Jurusan/Prodi } & $\begin{array}{c}\text { Pelaku } \\
\text { Wirausaha }\end{array}$ & $\begin{array}{c}\text { Non } \\
\text { Wirausaha }\end{array}$ \\
\hline 1 & Pendidikan Ekonomi S1 & 5 & 5 \\
2 & Ekonomi Pembangunan S1 & 1 & 3 \\
3 & Akuntansi S1 & 7 & 5 \\
4 & Akuntansi D3 & 3 & 3 \\
5 & Manajemen S1 & 8 & 4 \\
6 & Administrasi Perkantoran D3 & 2 & 4 \\
& & 26 & 24 \\
\hline
\end{tabular}

Wawancara singkat yang kami lakukan sebelum pengisian kuesioner menemukan bahwa sebagian besar responden belum/tidak pernah mengikuti pelatihan, pembekalan, seminar, workshop dan sejenisnya tentang kewirausahaan. Selain faktor kurangnya informasi dan sosialisasi dari penyelenggara juga karena minat mahasiswa itu sendiri untuk mengikuti kegiatan tersebut amat rendah. Bagi responden yang pernah mengikuti pelatihan kewirausahaan juga hanya dilaksanakan di internal kampus. Hanya beberapa dari mereka yang pernah mengikuti pelatihan kewirausahaan yang dilaksanakan oleh stakeholder lainnya seperti Dinas Koperasi, Perindustrian dan Perdagangan Provinsi Gorontalo dan Bank Indonesia Cabang Gorontalo. Dari sisi latar belakang pekerjaan orang tua, sebagian besar responden memang bukan berasal dari keluarga wirausaha. Rata-rata jenis profesi orang tua mereka adalah pegawai negeri (pada instansi vertikal maupun daerah) dan karyawan swasta. Hanya sebagian kecil responden menjawab latar belakang pekerjaan orang tua sebagai wiraswasta. Akibatnya dorongan orang tua agar anaknya aktif mencari pengalaman berusaha secara mandiri sangat kecil.

Mata kuliah kewirausahaan merupakan mata kuliah yang wajib diikuti oleh mahasiswa disemua jurusan/program studi di FEB-UNG. Salah satu metode yang digunakan adalah mahasiswa didorong untuk melakukan kegiatan wirausaha dengan membuat dan memasarkan produk yang dihasilkannya. Hal ini dilakukan untuk mendorong kreativitas mahasiswa dan mengetahui seberapa jauh kemampuan mahasiswa dalam menjadi wirausahawan. Bagi sebagian mahasiswa kegiatan ini dianggap sebagai media latihan untuk mengasah keterampilan dan minat berwirausaha, namun bagi sebagian yang lain aktivitas ini hanya tuntutan untuk mendapat nilai semata.

Selain itu, pengetahuan wirausaha dapat diperoleh mahasiswa tidak hanya melalui kuliah kewirausahaan, tetapi juga melalui seminar kewirausahaan, pelatihan kewirausahaan, maupun studi literatur yang dapat dilakukan secara mandiri ataupun berkelompok. Sebaliknya, sikap dan tindakan wirausaha kurang dapat dieksplorasi oleh mahasiswa secara mandiri. Padahal sikap wirausaha mencerminkan komponen 
afektif mahasiswa dalam menanggapi peluang usaha yang menyangkut komitmen terhadap pelaksanaan usaha. Tindakan wirausaha mencerminkan hal yang dilakukan oleh wirausaha dalam mencapai tujuannya dalam berwirausaha. Karakter wirausaha mahasiswa terdiri dari dua unsur utama yaitu kepribadian dan kepercayaan diri. Komponen kepribadian mencakup kebebasan, disiplin diri, dorongan dan keinginan, serta kemampuan menghadapi risiko.

\section{Rekapitulasi Tanggapan Responden}

Secara umum, faktor penentu wirausaha mahasiswa di FEB-UNG dapat diklasifikasikan ke dalam tiga bagian besar, yakni faktor internal (sikap dan kepribadian), eksternal (keluarga dan lingkungan sosial) dan kontekstual (dukungan pendidikan, pengalaman dan pembekalan kewirausahaan), dimana masing-masing faktor tersebut dijabarkan dalam butir-butir pertanyaan dengan tanggapan responden yang direkapitulasi sebagai berikut:

Tabel 4. Rekapitulasi Tanggapan Responden pada Faktor Internal

\begin{tabular}{|c|c|c|c|c|c|c|}
\hline & Pertanyaan & & & espo & & \\
\hline & Faktor Internal & SS & $\mathbf{S}$ & $\mathbf{N}$ & TS & STS \\
\hline 1 & $\begin{array}{l}\text { Saya adalah pribadi pekerja keras, cakap, dan kreatif karenanya lebih tertarik membuka usaha } \\
\text { sendiri dibanding bekerja dibawah pihak/institusi tertentu. }\end{array}$ & 10 & 23 & 12 & 5 & 0 \\
\hline 2 & $\begin{array}{l}\text { Saya yakin dan percaya bahwa segala potensi dan kapasitas/kemampuan yang saya miliki } \\
\text { adalah modal terbesar dan terbaik bagi kesuksesan saya di masa mendatang. }\end{array}$ & 13 & 24 & 11 & 2 & 0 \\
\hline 3 & $\begin{array}{l}\text { Saya menyadari kekurangan dan kelemahan pribadi, akan segera bisa diperbaiki bila saya } \\
\text { menjalankan bisnis sendiri dibanding bekerja pada pihak/institusi tertentu. }\end{array}$ & 10 & 25 & 10 & 4 & 1 \\
\hline 4 & $\begin{array}{l}\text { Saya yakin bekerja menuruti intuisi pribadi lebih menyenangkan dan berpotensi } \\
\text { mendatangkan keuntungan lebih besar dibanding bekerja menurut aturan-aturan yang ketat } \\
\text { pada pihak/institusi tertentu. }\end{array}$ & 24 & 15 & 9 & 2 & 0 \\
\hline 5 & $\begin{array}{l}\text { Saya merasa dapat berlaku lebih jujur, terbuka, dan bertanggungjawab bila menjalankan usaha } \\
\text { sendiri dibanding bekerja pada pihak/institusi tertentu. }\end{array}$ & 14 & 21 & 8 & 5 & 2 \\
\hline 6 & $\begin{array}{l}\text { Saya merasa lebih bebas, mandiri, dan lebih produktif bila menjalankan usaha sendiri } \\
\text { dibanding bekerja pada pihak/institusi tertentu. }\end{array}$ & 30 & 10 & 6 & 4 & 0 \\
\hline 7 & $\begin{array}{l}\text { Saya merasa lebih tertantang bekerja dengan risiko sekaligus potensi keuntungan yang besar } \\
\text { dibanding yang resiko dan potensi laba kecil/biasa-biasa saja. }\end{array}$ & 18 & 12 & 15 & 3 & 2 \\
\hline 8 & $\begin{array}{l}\text { Saya merasa lebih menghargai dan menggunakan waktu lebih efisien bila menjalankan usaha } \\
\text { sendiri dibanding bekerja pada pihak/institusi tertentu. }\end{array}$ & 11 & 25 & 8 & 5 & 1 \\
\hline 9 & $\begin{array}{l}\text { Saya yakin dengan memanfaatkan peluang bisnis disekitar lingkungan tempat tinggal akan } \\
\text { membuat saya lebih bahagia dibanding membuat banyak surat lamaran pekerjaan }\end{array}$ & 18 & 13 & 12 & 6 & 1 \\
\hline 10 & $\begin{array}{l}\text { Semangat untuk memperbaiki kualitas produk dan pelayanan kepada pelanggan membuat } \\
\text { saya lebih tertarik berwirausaha dibanding menjadi pegawai/karyawan }\end{array}$ & 16 & 16 & 13 & 4 & 1 \\
\hline 11 & $\begin{array}{l}\text { Saya lebih memiliki kepuasan dan kebanggaan bila menjadi wirausaha sukses dibanding } \\
\text { pegawai/karyawan berprestasi }\end{array}$ & 16 & 15 & 10 & 7 & 2 \\
\hline 12 & $\begin{array}{l}\text { Berani menerima tantangan dan peluang bisnis adalah faktor paling menentukan gagal atau } \\
\text { suksesnya wirausahawan }\end{array}$ & 11 & 26 & 9 & 3 & 1 \\
\hline 13 & Dorongan harga diri (self esteem) adalah faktor menentukan minat berwirausaha & 14 & 19 & 10 & 6 & 1 \\
\hline 14 & $\begin{array}{l}\text { Saya akan menikmati waktu luang lebih berkualitas bila menjadi wirausaha dibanding } \\
\text { pegawai/karyawan }\end{array}$ & 13 & 18 & 11 & 6 & 2 \\
\hline
\end{tabular}


Tabel 5. Rekapitulasi Tanggapan Responden pada Faktor Eksternal

\section{Pertanyaan}

\section{Faktor Internal}

1 Orang tua dan keluarga besar umumnya berprofesi sebagai wirausaha dan aktif mendorong saya untuk menekuni wirausaha

2 Orang tua dan keluarga besar umumnya berprofesi sebagai wirausaha tetapi mereka mendorong saya untuk berkarir sebagai pegawai/karyawan

3 Orang tua dan keluarga besar umumnya berprofesi sebagai pegawai/karyawan dan aktif mendorong saya untuk berkarir sebagai pegawai/karyawan

4 Orang tua dan keluarga besar umumnya berprofesi sebagai pegawai/karyawan tetapi mereka mendorong saya untuk menekuni wirausaha

5 Saya tumbuh dan besar dari lingkungan sosial yang umumnya berprofesi sebagai pegawai/ karyawan

6 Saya tumbuh dan besar dari lingkungan sosial yang umumnya berprofesi sebagai wirausaha/ pengusaha

7 Menurut saya, berstatus pegawai/karyawan memperoleh penghargaan lebih tinggi di mata masyarakat dibanding menjadi wirausahawan

8 Menurut saya, menjadi wirausahawan memperoleh penghargaan lebih tinggi di mata masyarakat dibanding berstatus PNS/karyawan

9 Orang tua dan keluarga yakin bahwa saya akan lebih sukses bila berwirausaha dibanding menjadi PNS/karyawan

10 Orang tua dan keluarga yakin bahwa saya akan lebih sukses bila menjadi PNS/karyawan dibanding berwirausaha

11 Dari sisi status sosial dan jaminan ketentraman hari tua, saya lebih berminat menjadi wirausahawan dibanding PNS/karyawan

12 Menurut saya, persaingan global, nasional dan lokal memungkinkan saya cenderung lebih sukses bila kelak menjadi wirausaha dibanding PNS/karyawan

13 Saya yakin dapat mengelola waktu dengan baik antara urusan pribadi, kuliah/akademik, menjalankan usaha dan bergaul dgn lingkungan

\begin{tabular}{|c|c|c|c|c|}
\hline SS & S & $\mathbf{N}$ & TS & STS \\
\hline 12 & 14 & 11 & 9 & 4 \\
\hline 6 & 9 & 11 & 14 & 10 \\
\hline 7 & 9 & 14 & 13 & 8 \\
\hline 8 & 11 & 14 & 10 & 7 \\
\hline 6 & 15 & 19 & 5 & 5 \\
\hline 5 & 5 & 19 & 15 & 6 \\
\hline 5 & 15 & 10 & 13 & 7 \\
\hline 7 & 13 & 10 & 15 & 5 \\
\hline 9 & 13 & 19 & 7 & 2 \\
\hline 3 & 8 & 18 & 13 & 9 \\
\hline 9 & 23 & 10 & 7 & 1 \\
\hline 10 & 22 & 10 & 7 & 1 \\
\hline 10 & 25 & 10 & 4 & 1 \\
\hline
\end{tabular}

Tabel 6. Rekapitulasi Tanggapan Responden pada Faktor Kontekstual

\begin{tabular}{|c|c|c|c|c|c|c|}
\hline & \multirow[b]{2}{*}{ Faktor Internal } & \multicolumn{5}{|c|}{ Respon } \\
\hline & & SS & $\mathbf{S}$ & $\mathbf{N}$ & TS & STS \\
\hline 1 & $\begin{array}{l}\text { Pengetahuan dan keterampilan wirausaha yang diperoleh dari pendidikan formal merupakan } \\
\text { faktor penting untuk menjalankan bisnis }\end{array}$ & 11 & 25 & 12 & 2 & 0 \\
\hline 2 & $\begin{array}{l}\text { Pengetahuan dan keterampilan wirausaha yang diperoleh dari pendidikan non-formal; } \\
\text { pelatihan, workshop, seminar dan lain-lain merupakan faktor penting untuk menjalankan bisnis }\end{array}$ & 10 & 25 & 13 & 2 & 0 \\
\hline 3 & $\begin{array}{l}\text { Kurikulum dan pembelajaran di FEB-UNG lebih menitikberatkan penguasaan teori daripada } \\
\text { penerapan praktis }\end{array}$ & 9 & 25 & 10 & 5 & 1 \\
\hline 4 & $\begin{array}{l}\text { Pengajar, metode pembelajaran dan fasilitas di FEB secara sinergi mengoptimalkan } \\
\text { peningkatan kemampuan/kompetensi mahasiswa }\end{array}$ & 5 & 12 & 22 & 8 & 3 \\
\hline 5 & $\begin{array}{l}\text { Proses pembelajaran MK kewirausahaan diisi oleh pengetahuan tentang nilai-nilai, semangat, } \\
\text { jiwa, sikap dan perilaku agar memiliki pemikiran kewirausahaan }\end{array}$ & 18 & 22 & 5 & 4 & 1 \\
\hline
\end{tabular}


6 Proses MK kewirausahaan berisi penanaman empatisme sosial-ekonomi, agar dapat merasakan suka duka berwirausaha dan memperoleh pengalaman empiris dari para wirausaha terdahulu

7 Proses pembelajaran kewirausahaan membekali teknik produksi agar dapat berproduksi atau menghasilkan produk baik berupa barang, jasa maupun ide

8 Proses pembelajaran kewirausahaan membekali teknik-teknik antisipasi terhadap berbagai hal yang mungkin dalam berwirausaha baik berupa persoalan, masalah maupun risiko lainnya

9 Pengajar MK kewirausahaan memiliki kompetensi akademik dan keterampilan praktis yang memadai sesuai harapan saya

10 Pengajar tidak berkompeten dan tidak terampil dalam menjalankan MK kewirausahaan

11 UNG memfasilitasi tumbuhnyawirausaha baru dengan menyediakan lab, galeri, program inkubator, pelatihan, workshop dan sejenisnya

12 FEB memfasilitasi tumbuhnyawirausaha baru dengan menyediakan lab, galeri, program inkubator, pelatihan, workshop dan sejenisnya

\begin{tabular}{|c|c|c|c|}
\hline 14 & 22 & 8 & 5 \\
\hline 15 & 22 & 8 & 4 \\
\hline 14 & 23 & 9 & 3 \\
\hline 9 & 14 & 18 & 7 \\
\hline 2 & 7 & 17 & 19 \\
\hline 11 & 14 & 12 & 10 \\
\hline 8 & 10 & 15 & 12 \\
\hline 5 & 16 & 18 & 7 \\
\hline 5 & 13 & 18 & 11 \\
\hline
\end{tabular}

\section{PEMBAHASAN}

Studi mengenai faktor determinan minat wirausaha mahasiswa masih terbuka luas untuk dielaborasi dalam berbagai konteks. Penelitian ini didasari oleh masalah rendahnya minat mahasiswa FEB-UNG untuk berwirausaha. Data yang kami peroleh dari Pusat Kreativitas Mahasiswa (PKM) UNG menunjukkan bahwa selang tahun 20122013 tidak ada mahasiswa FEB-UNG baik secara perorangan maupun kelompok yang lolos seleksi administrasi (tahap I). Mahasiswa FEB yang kami pilih secara acak yang bertemu di koridor kampus, bila ditanyakan tentang rencana setelah lulus kuliah, baik mahasiswa tingkat pertama (semester awal), tingkat menengah maupun tingkat akhir (semester tujuh ke atas), kebanyakan memilih ingin menjadi pegawai negeri sipil (PNS) meskipun mereka tahu bahwa kesempatan untuk menjadi PNS sangat terbatas karena kuota dan formasi yang semakin kecil. Bahkan belakangan media cetak melaporkan terjadi sejumlah kasus penyuapan/penyogokan hingga puluhan juta rupiah yang harus diberikan peminat PNS kepada oknum-oknum yang menjanjikan dapat meluluskan. Alternatif lain, mereka ingin menjadi karyawan perusahaan dan pekerja sektor formal lainnya. Setali tiga uang dengan peluang menjadi PNS, kesempatan kerja di sektor ini juga makin terbatas karena standar/ kualifikasi pelamar yang ditentukan penyedia pekerjaan cukup tinggi dan persaingan yang ketat akibat kualifikasi pelamar yang cukup tinggi.

Kegiatan sosialisasi dan penelitian terkait upaya pengembangan wirausaha baru di Gorontalo telah kami laksanakan beberapa tahun terakhir ini. Di internal kampus UNG, kami integrasikan pembelajaran berbasis hasil riset (research based learning) dan pembelajaran berpusat pada peserta didik (student centered learning). RBL dan SCL mengarahkan mahasiswa untuk mengeksplorasi minat dan kemampuannya secara mandiri sehingga tumbuh pemahaman dan motivasi berwirausaha serta kemampuan menulis proposal usaha (bisnis plan) yang baik. Mahasiswa belajar berwirausaha berdasarkan teori dan bukti empiris di lapangan (contextual teaching learning) sehingga semakin tertarik untuk berwirausaha, membuka lapangan kerja dan menciptakan pendapatan dan kesejahteraan bagi diri sendiri dan masyarakat di lingkungannya kelak.

Secara umum, faktor penentu wirausaha mahasiswa di FEB-UNG dapat diklasifikasikan ke dalam tiga bagian besar, yakni faktor internal (sikap dan kepribadian), eksternal (keluarga dan lingkungan sosial) dan kontekstual (dukungan pendidikan, pengalaman dan pembekalan kewirausahaan), dimana masing-masing faktor tersebut dijabarkan dalam butir-butir pertanyaan dengan tanggapan responden yang direkapitulasi seperti disajikan pada Tabel 4., Tabel 5., dan Tabel 6. 
Dari 14 pertanyaan tentang faktor internal (personality) terdapat beberapa faktor yang cukup dominan dipilih oleh responden. 52 persen setuju dan 22 persen sangat setuju bahwa mereka berani menerima tantangan dan peluang bisnis (poin 12). Hal ini mengindikasikan bahwa proses belajar mengajar kewirausahaan di FEB-UNG sudah dalam jalur yang benar dan memberi kesan bahwa sebagai pembeda dari yang bukan wirausaha, dibutuhkan karakter keberanian mengambil risiko.

Masing-masing 50 persen setuju mereka mampu memperbaiki kelemahan (3) dan menggunakan waktu lebih efisien (8) bila menjalankan usaha sendiri. Diatas 40 persen setuju bahwa mereka adalah pekerja keras, cakap, kreatif, memiliki potensi dan kapasitas untuk sukses berwirausaha (1) serta berlaku jujur, terbuka dan bertanggung jawab (5). 60 persen sangat setuju bahwa mereka lebih bebas, mandiri dan lebih produktif bila berwirausaha (6). 48 persen sangat setuju bahwa bekerja menurut intuisi pribadi (4) lebih menyenangkan dan mendatangkan keuntungan lebih besar dibanding bekerja dibawah ketatnya aturan. Meskipun demikian 30 persen responden bersikap netral/ragu atas kemampuan mereka mengambil resiko (poin 7), 26 persen netral/ragu akan mampu memperbaiki kualitas produk dan pelayanan kepada pelanggan (poin 10).

Bila dikaitkan dengan faktor jenis kelamin, beberapa penelitian memperlihatkan laki-laki memiliki minat lebih tinggi dibanding perempuan (Rasheed, 2000; Nishanta, 2008). Namun hal tersebut tidak seperti yang kami temukan pada mahasiswa pelaku wirausaha di FEB-UNG. Sebagian besar responden mahasiswi telah menjalankan wirausaha sambil kuliah dalam bentuk usaha Multi Level Marketing (MLM), makanan ringan (snack) yang dipromosikan online, pulsa elektronik, pernakpernik maupun kerajinan tangan (handycraft) khas daerah. Seperti halnya riset Johnston et al. (2010) bahwa mahasiswi lebih luwes dalam berwirausaha sambil kuliah dibanding mahasiswa. Kurnianto dan Sulistya (2012) menyatakan, untuk lebih memperkuat minat mahasiswa berwirausaha dibutuhkan upaya meningkatkan faktor kepribadiannya, meliputi kebutuhan berprestasi, locus of control, bersahabat dengan ketidakpastian, keberanian mengambil risiko dan percaya diri. Faktor ini dapat ditingkatkan melalui pengembangan soft-skill. Di samping itu perbaikan kurikulum, metode pembelajaran dan pengajaran tetap perlu untuk dibenahi. Seperti dijelaskan dalam penelitian Nastiti dan kawan-kawan (2010) yang membandingkan minat wirausaha mahasiswa Cina dan Indonesia, menyimpulkan bahwa minat berwirausaha mahasiswa Cina dipengaruhi oleh kebutuhan akan pencapaian, lokus kendali, efikasi pribadi, dan kesiapan instrumen, sedangkan mahasiswa Indonesia oleh efikasi pribadi.

Dari 13 pertanyaan tentang faktor eksternal (Tabel 4.b) terdapat beberapa faktor yang cukup dominan dipilih oleh responden. 50 persen setuju mereka dapat mengelola waktu untuk urusan pribadi, akademik, usaha dan bergaul dengan lingkungan sekitar (poin 13). 46 persen setuju bahwa menjadi wirausahawan meningkatkan status sosial dan jaminan hari tua dibanding karyawan (11). Dan 44 persen setuju bahwa persaingan global, nasional dan lokal merupakan peluang tersendiri untuk meraih sukses sebagai wirausaha (12). Tetapi pada poin 3, 4, 5, 6, 9 dan 10 menunjukkan keragu-raguan yang mendekati 40 persen.

Faktor pekerjaan orangtua merupakan faktor yang menarik untuk diteliti di Indonesia. Tidak sedikit hasil riset menjelaskan bahwa rendahnya minat dan pertumbuhan wirausahawan muda di Indonesia disinyalir antara lain disebabkan oleh minimnya contoh dan dorongan lingkungan keluarga kepada anak. Hal ini didukung oleh hasil penelitian Tjahjono (2008) yang menjelaskan bahwa norma subyektif yang positif yaitu kemauan mahasiswa untuk mengikuti saran orang-orang yang mereka anggap penting untuk berwirausaha seperti orang tua, saudara dan dosen, akan semakin meningkatkan kontrol keprilakuan mahasiswa, yang merupakan modal mahasiswa untuk berwirausaha.

Sementaraitu masih banyak orangtuayang bekerja sebagai pegawai juga mengharapkan anaknya bekerja sebagai pegawai yang dinilai memiliki risiko lebih kecil dibandingkan menjadi pengusaha. Sebaliknya orang tua yang berprofesi sebagai wirausaha diyakini dapat menjadi panutan (entrepreneurial role model) yang akan membentuk minat anak untuk berwirausaha di masa depan (Galoway, et al., 2006).

Dari 14 pertanyaan tentang faktor kontekstual (Tabel 4.c) terdapat beberapa faktor yang cukup dominan dipilih oleh responden. 50 persen setuju bahwa pendidikan formal ditunjang pelatihan, workshop, seminar, praktikum kewirausahaan sebagai faktor penting minat wirausaha. Tetapi mahasiswa jumlah yang sama setuju bahwa kurikulum dan pembelajaran di FEB-UNG masih menitikberatkan 
penguasaan teori dan dibanding penerapan praktis. Pengetahuan mahasiswa mengenai kewirausahaan yang lebih tinggi dibandingkan dengan sikap dan tindakan dalam berwirausaha mengindikasikan proses belajar mengajar kewirausahaan masih fokus pada penajaman teori, dimana dosen biasanya menjadi pusat pembelajaran (teacher centered learning).

Pendekatan budaya melihat bahwa rendahnya budaya wirausaha bukan hanya dipengaruhi latar belakang pekerjaan orang tua sebagai pegawai/ karyawan. Generasi muda yang lahir dari lingkungan petani, nelayan dan pekerja sektor informal lainnya umumnya juga memiliki pola pikir yang cenderung menjadi pencari kerja (job seeker) daripada pencipta kerja (job creator). Pendekatan psikologis melihat hal ini terjadi karena lemahnya mentalitas dan kepribadian generasi muda Indonesia seperti keinginan untuk berprestasi, keberanian mengambil resiko, keuletan, daya juang, kepercayaan pada diri sendiri, kreativitas, inovasi dan lain sebagainya. Pendekatan pendidikan melihat bahwa kondisi ini terjadi karena lemahnya pendidikan kewirausahaan di bangku sekolah maupun perguruan tinggi. Baik dilihat dari aspek kurikulum, pengajar, proses pembelajaran, sarana pembelajaran, sumber-sumber pembelajaran maupun evaluasinya, pelaksanaan pendidikan kewirausahaan masih bermasalah secara mendasar (Rianti, 2003).

\section{KESIMPULAN}

Berdasarkan uraian hasil dan pembahasan maka dapat disimpulkan bahwa minat mahasiswa FEB-UNG untuk berwirausaha secara umum relatif rendah. Hal ini ditunjukkan oleh kurangnya individu dan kelompok mahasiswa wirausaha; rendahnya keterlibatan mahasiswa dalam pelatihan, pembekalan, seminar dan sejenisnya didalam maupun diluar lingkungan kampus; serta kurangnya proposal bisnis (bisnis plan) yang diajukan/berkompetisi di PKMUNG.

Karakteristik individual, lingkungan keluarga dan sosiodemografi serta dukungan akademik merupakan faktor-faktor yang paling dominan menentukan tinggi rendahnya minat wirausaha mahasiswa FEB-UNG. Kecenderungan tingginya minat wirausaha mahasiswa karena adanya perasaan lebih bebas, mandiri dan produktif bila berwirausaha; senang bekerja menurut intuisi pribadi; keyakinan pada kemampuan dan potensi diri; serta keberanian menerima tantangan dan mengambil resiko. Masih rendahnya minat wirausaha mahasiswa karena mayoritas orang tua dan keluarga berprofesi pegawai negeri dan karyawan swasta sehingga mengarahkan anak-anaknya untuk melanjutkan karir di sektor formal. Persepsi masyarakat bahwa status sosial dan jaminan kesejahteraan pegawai lebih baik dibanding wirausaha juga membuat minat wirausaha mahasiswa rendah. Iklim pembelajaran kewirausahaan masih didominasi aspek teoritis juga menjadi salah satu faktor yang mempengaruhi masih rendahnya minat wirausaha mahasiswa. Mahasiswa tidak memiliki orientasi dan pengalaman lapangan karena model pembelajaran masih konvensional. Fasilitas berbentuk fisik, modal dan program yang dapat diakses di internal kampus ada tetapi relatif terbatas sehingga tidak menunjang minat mahasiswa berwirausaha.

Alternatif cara yang dapat dilakukan FEBUNG untuk meningkatkan minat wirausaha mahasiswa diantaranya melalui (a) memperbanyak frekuensi praktek kewirausahaan, sosialisasi dan akses terhadap informasi tentang kewirausahaan di internal kampus juga dibuka seluas-luasnya kepada mahasiswa, (b) melaksanakan pembelajaran kontekstual secara periodik berupa studi lapangan pada Usaha Mikro, Kecil dan Menengah (UMKM) di area kampus terutama yang dimiliki dan dikelola oleh alumni, (c) menyediakan dan melengkapi fasilitas kewirausahaan yang ada di internal kampus seperti laboratorium, galeri, bengkel dan sejenisnya, (d) mengadakan program khusus seperti inkubator bisnis dan lomba-lomba penulisan rencana usaha bagi mahasiswa (business plan) dengan hadiah/bonus tertentu yang berdampak pada meningkatnya minat dan keterampilan berwirausaha, (e) alokasi anggaran memadai kepada kelompok-kelompok mahasiswa yang setelah melalui seleksi tertentu memenuhi syarat dan memiliki prospek untuk mengembangkan usaha, dan (f) membangun jaringan pengembangan wirausaha terpadu dengan stakeholder lokal yang memiliki program sejenis seperti Dinas Koperasi Perindustrian dan Perdagangan, Bank Indonesia dan Kamar Dagang dan Industri di Gorontalo.

\section{DAFTAR PUSTAKA}

Alma, B. 2009. Kewirausahaan; untuk Mahasiswa dan Umum (Edisi Revisi). Bandung: Penerbit Alfabeta.

Ciputra. 2009. Quantum Leap Entrepreneurship; Mengubah Masa Depan Bangsa dan Masa Depan Anda (Cetakan ke 4). Jakarta: Elex Media Komputindo. 
Galloway. L. 2006. Identifying Entrepreneurial Potential in Students. Working Paper 006, National Council for Graduate Entrepreneurship

Gurbuz, G \& Aykol, S. 2008. Entrepreneurial Intentions of Young Educated Public in Turkey. Journal of Global Strategic Management, 4(1): 47-56.

Hisrich, R. D. \& Peters, M. P. 2000. Entrepreneurship: Starting, Developing and Managing A New Enterprises (5th Edition). New York: McGraw-Hill.

Johnston, K. A., et al. 2010. Identifying ICT Entrepreneurship Potential in Students. Proceedings of Informing Science \& IT Education Conference (InSITE), (June): 21-24.

Kemendikbud. 2012. Panduan Program Mahasiswa Wirausaha. Direktorat Pembelajaran dan Kemahasiswaan, Direktorat Jenderal Pendidikan Tinggi.

Kurnianto, B. S. \& Sulistya E. P. 2012. Menumbuhkembangkan Minat Berwirausaha bagi Mahasiswa Di Lingkungan Perguruan Tinggi. Prosiding Seminar \& Konferensi Nasional Manajemen Bisnis, (Mei).

Lee, S. H. \& Wong, P. K. 2004. An Exploratory Study of Technopreneurial Intentions; A Career Anchor Perspective. Journal of Business Venturing, 19(1): 7-28.

Mopangga, H. et al.. 2013. Komoditas Unggulan Lokal sebagai Sumber Inovasi dan Wirausaha Mahasiswa; Pengalaman dari Gorontalo. Prosiding Konferensi Nasional Inovasi dan Technopreneurship RAMP-IPB Bogor, 195-202.

Nastiti, Tur., et al. 2010. Minat Berwirausaha Mahasiswa Indonesia Dan Cina. Jurnal Manajemen dan Bisnis, 9(2).

Niode, I. Y. 2007. Wirausaha Sebagai Alternatif Solusi Masalah Pengangguran. Jurnal Inovasi, 4(1): 91-99.

Nishanta, B. 2008. Influence of Personality Traits and Socio-demographic Background of Undergraduate Students on Motivation for Entrepreneurial Career: The Case of Srilanka. Paper was presented at the Euro-Asia Management Studies Association (EAMSA) Conference, Japan.

Priyanto, S. H. 2008. Di dalam Jiwa ada Jiwa: The Backbone and the Social Construction of Entrepreneurships. Pidato Pengukuhan Guru Besar Universitas Kristen Satya Wacana

Rasheed, H. S. 2000. Developing Entrepreneurial Potential in Youth: The Effects of Entrepreneurial. Education and Venture Creation http:// USASEB2001proceedings, 063.
Rianti, B. P. 2003. Kewirausahaan Dari Sudut Pandang Psikologi Kepribadian. Jakarta: Penerbit Grasindo.

Siswadi, Y. 2013. Analisis Faktor Internal, Eksternal dan Pembelajaran Kewirausahaan yang Mempengaruhi Minat Mahasiswa dalam Berwirausaha. Jurnal Manajemen dan Bisnis, (13) 1 .

Soegoto, E. S. 2009. Entrepreneurship; Menjadi Pebisnis Ulung. Jakarta: Penerbit PT. Elex Media Komputindo.

Suherti, L. \& Sirine, H. 2011. Faktor-Faktor yang Berpengaruh Terhadap Niat Kewirausahaan (Entrepreneurial Intention); Studi Terhadap Mahasiswa Universitas Kristen Satya Wacana, Salatiga. Jurnal Manajemen dan Kewirausahaan, (13)2: 124-134.

Tjahjono, H. K. \& Ardi, H. 2008. Kajian Niat Mahasiswa Manajemen Universitas Muhammadiyah Yogyakarta untuk Menjadi Wirausaha. Jurnal Manajemen dan Bisnis, 16(1): 46-63.

Wu, S. \& Wu, L. 2008. The Impact of Higher Education on Entrepreneurial Intentions of University Students in China. Journal of Small Business and Enterprise Development, 15(4): 752-774.

Zain, et al. 2010. Entrepreneurship Intention Among Malaysian Business Students. Canadian Social Science, 6(3): 34-44.

Zimmerer, W. T. 2002. Essentials of Entrepreneurship and Small Business Management (3rd Edition). New York: Prentice-Hall.

\section{UCAPAN TERIMA KASIH}

Rasa syukur dan terima kasih penulis sampaikan kepada; Pertama, Yang Terhormat Dekan Fakultas Ekonomi dan Bisnis yang telah menyetujui dan merekomendasikan usul hingga laporan penelitian ini diselesaikan. Kedua, Yang Terhormat Ketua Lembaga Penelitian bersama segenap Tim Penyeleksi yang telah meluluskan dan memfasilitasi kegiatan penelitian ini dengan dukungan dana dari PNBP-BLU Tahun Anggaran 2013-2014 dalam skim Penelitian Pengembangan Program studi. Last but not least, Yang Mulia Rektor Universitas Negeri Gorontalo atas dorongan semangat dan motivasi kepada segenap sivitas akademika untuk terus meningkatkan kualitas riset dan publikasi ilmiah. 